\title{
PENERAPAN MODEL COOPERATIVE LEARNING TIPE PICTURE AND PICTURE UNTUK MENINGKATKAN KEMAMPUAN BERPIKIR KRONOLOGIS SISWA DALAM PEMBELAJARAN SEJARAH
}

\author{
Oleh : \\ Noer Hadi Pratomo, Erlina Wiyanarti, Yeni Kurniawati S ${ }^{1}$
}

\begin{abstract}
The background of this research arose from the researcher's concern to the students' lack of ability to think chronologically in XI IPS 3 classroom. It is identified by their ignorance to temporal structure concept and low ability in demonstrating the concept of continuity and causality. So the aim of this study focuses in improving the students' chronological thinking ability through the implementation of cooperative learning model picture and picture type. This cooperative learning model picture and picture type allows students to work together in groups to achieve the learning purpose through pictures as its media. Therefore, by using pictures as media in learning avtivities it is aimed to help students reconstructing historical events. The method used in this study is a classroom action research (CAR), the research design is adapted from the work of Kemmis and Mc. Taggart where it consists of several cycle and each includes several phases; planning (plan), implementation (act), observations (Observe) and reflection (Reflect). The data was collected from observation, interviews, and documentation. Based on the results carried out during the four cycles, it can be concluded that there is a significant increase in the students' ability to think chronologically. The increase was identified while the implementation of cooperative learning model picture and picture type, the students showed high motivation towards the learning materials, enthusiasm to work together in groups to complete the task, the students become accustomed to write down timeline and the increase of ability to reconstruct events in chronological order. It shows that the implementation of cooperative learning model picture and picture type can improve the students' ability to think chronologically.
\end{abstract}

Key Words: Chronological Thinking, Picture and Picture Type

1Penulis merupakan mahasiswa Departemen Pendidikan Sejarah FPIPS UPI, Erlina Wiyanarti dan Yeni Kurniawati sebagai Pembimbing I dan II. Penulis dapat dihubungi melalui No. HP o85722698503 dan alamat email: nhpratomo@gmail.com 


\section{PENDAHULUAN}

Pendidikan merupakan bagian penting dari kehidupan masyarakat dan sudah menjadi suatu kebutuhan bagi manusia terutama pada era global seperti sekarang. Melalui pendidikan, manusia berupaya untuk mengembangkan setiap potensi yang ada dalam dirinya sehingga dapat menjadi manusia yang ideal. Upaya untuk mengembangkan potensi tersebut telah diamanatkan dalam Undang-Undang Sisdiknas No.20 Tahun 2003 bahwa:

tujuan pendidikan nasional adalah mengembangkan potensi peserta didik agar menjadi manusia yang beriman dan bertakwa kepada Tuhan Yang Maha Esa, berakhlak mulia, sehat, berilmu, cakap, kreatif, mandiri, dan menjadi warga negara yang demokratis serta bertanggung jawab.

Pendidikan sejarah salah satunya, adalah mata pelajaran yang berpotensi untuk membentuk manusia yang ideal. Semenjak diberlakukannya kurikulum 2013, pendidikan sejarah mendapat alokasi waktu yang cukup banyak dibandingkan mata pelajaran lainnya.

Berkaitan dengan kurikulum, pembelajaransejarah saatinimengacupada kurikulum 2013 dan memiliki beberapa tujuan. Adapun tujuan pembelajaran sejarah berdasarkan Kurikulum 2013 (Kemendikbud, 2013, hlm. 89), adalah sebagai berikut:

1. membangun kesadaran peserta didik tentang tentang pentingnya konsep waktu dan tempat/ruang dalam rangka memahami perubahan dan keberlanjutan dalam kehidupan bermasyarakat dan berbangsa di Indonesia;

2. mengembangkan kemampuan berpikir historis (historical thinking) yang menjadi dasar untuk kemampuan berpikir logis, kreatif, inspiratif, dan inovatif;

3. menumbuhkan apresiasi dan penghargaan peserta didik terhadap peninggalan sebagai bukti peradaban bangsa Indonesia di masa lampau;

4. menumbuhkan pemahaman peserta didik terhadap diri sendiri, masyarakat, dan proses terbentuknya bangsa indonesia melalui sejarah yang panjang dan masih berproses hingga masa kini dan masa yang akan datang;

5. menumbuhkan kesadaran dalam diri peserta didik sebagai bagian dari bangsa Indonesia yang memiliki rasa bangga dan cinta tanah air, melahirkan empati dan perilaku toleran yang dapat diimplementasikan dalam berbagai bidang kehidupan masyarakat dan bangsa;

6. mengembangkan perilaku yang didasarkan pada nilai dan moral yang mencerminkan karakter diri, masyarakat dan bangsa; dan

menanamkan sikap berorientasi kepada masa kini dan masa depan.

Berdasarkan tujuan-tujuan yang telah dipaparkan di atas, pembelajaran sejarah diharapkan dapat memfasilitasi siswa untuk mengembangkan potensi sikap, pengetahuan, dan keterampilan pada tingkat yang maksimal. Dalam penelitian ini, peneliti akan mengkaji tujuan pembelajaran sejarah menurut kurikulum 2013 yaitu kemampuan berpikir historis. Tetapi untuk penelitian kali ini akan lebih difokuskan kepada bagian dari berpikir historis (historical thinking) yaitu kemampuan berpikir kronologis (chronological thinking). Kemampuan berpikir kronologis tersebut 
perlu dikembangkan dalam pembelajaran sejarah karena kemampuan tersebut adalah instrumen penting yang harus dimiliki siswa sebagai landasan berpikir kesejarahan.

Dilatar belakangi hasil observasi awal di kelas XI IPS 3 di SMA Negeri 13 Bandung peneliti menemukan beberapa permasasalahan dalam pembelajaran sejarah khususnya yang berkaitan dengan kemampuan berpikir kronologis, diantaranya (1) berdasarkan aktivitas tanya jawab antara guru dan siswa, kemampuan dalam mengingat angka tahun peristiwa masih rendah. Hal ini ditunjukkan dari jawaban siswa yang belum tepat (2) berdasarkan aktivitas diskusi, siswa belum dapat menjelaskan kesinambungan antara satu peristiwa dengan peristiwa lainnya. Hal ini ditandai ketika beberapa siswa diminta untuk menyampaikan ulang pemahamannya, siswa belum mampu melakukannya. (3) berdasarkan hasil tugas siswa dalam membuat komik sejarah menunjukkan bahwa kemampuan merekonstruksi masih rendah, hal ini dapat dilihat dari belum tercantumkannya tahun-tahun penting dalam komiktersebut. Berdasarkan hasil temuan tersebut, maka kemampuan berpikir kronologis siswa dalam pembelajaran sejarah dapat dikatakan rendah. Apabila hal ini dibiarkan maka akan berakibat pada penurunan kualitas pembelajaran sejarah.

Berdasarkan temuan tersebut, maka perlu adanya solusi untuk menyelesaikan permasalahan yang ada. Salah satunya adalah dengan menerapkan model pembelajaran yang mampu meningkatkan kemampuan berpikir kronologi sehingga tujuan pembelajaran sejarah dapat tercapai.Untukmeningkatkankemampuan tersebut dapat dilakukan dengan berbagai model pembelajaran, salah satunya dengan penerapan model cooperative learning tipe picture and picture dalam pembelajaran sejarah. Selain untuk meningkatkan kemampuan berpikir kronologis itu sendiri, peneliti memilih penerapan model cooperative learning tipe picture and picture adalah untuk mencapai kerja sama sebagai kompetensi yang harus dicapai khususnya pembelajaran sejarah.

Chronological thinking atau berpikir kronologis merupakan satu bentuk kemampuan dasar atau awal yang penting untuk dikuasai siswa, sehingga ini dapat memfasilitasi siswa dalam memahami tingkat berpikir kesejarahan yang lebih tinggi secara komprehensif. Pengertian mengenai berpikir kronologis dipaparkan oleh Nash dan Phenix dalam Ma'mur (2008) bahwa

chronological thinking (berpikir kronologis), yaitu membangun tahap awal dari pengertian atas waktu (masa lalu, sekarang dan masa datang), untuk mengidentifikasi urutan waktu atas setiap kejadian, mengukur waktu kalender, menginterpretasikan dan menyusun garis waktu, serta menjelaskan konsep kesinambungan sejarah dan perubahannya (hlm. 201).

Selain itu, terdapat pula indikator lainnya yang menunjukkan kemampuan berpikir kronologis yang dikembangkan oleh National Center of History in the School yaitu

terampil merangkai peristiwa yang terjadi pada masa lalu, masa kini, dan masa yang akan datang dalam sebuah kalender waktu. Terampil membuat, menginterpretasikan dan menjelaskan pola sejarah berdasarkan bagan waktu, terutama terkait dengan kontinuitas dan perubahan. (Arif dalam Winarto, 2014, 
hlm. 26)

Berdasarkan pengertian dan indikator yang telah dijelaskan di atas mengenai berpikir kronologis, maka peneliti menyimpulkan berpikir kronologis sebagai suatu proses. Proses tersebut dibangun mulai dari pemahaman siswa mengenai konsepwaktuyangbenar,identifikasiwaktu terjadinya suatu peristiwa, kemampuan mengurutkan peristiwa secara kronologis, kemampuan menghubungkan sebabakibat (kausalitas) dalam suatu peristiwa sejarah, yang kemudian direkonstruksi berdasarkan urutan yang kronologis sebagai suatu peristiwa sejarah.

Menurut Eggen dan Kauchak (2012, hlm. 136) pembelajaran kooperatif mengandung pengertian tentang sekelompok strategi mengajar yang memberikan peran terstruktur bagi siswa seraya menekankan interaksi siswa-siswa. Tujuan paling penting dari pembelajaran kooperatif menurut Slavin (2008, hlm.33) adalah untuk memberikan para siswa pengetahuan, konsep, kemampuan, dan pemahaman yang mereka butuhkan supaya bisa menjadi anggota masyarakat yang bahagia dan memberikan kontribusi.

Tipe pembelajaran picture and picture menggunakan gambar sebagai perangkat utama atau media dalam pembelajaran dan kemudian dipasangkan secara berurutan sehingga menjadi urutan yang logis. Tipe Pembelajaran picture and picture menurut Rosalin dalam Lestari (2011, hlm. 15) dalam bukunya peneliti memperoleh pemahaman bahwa tipe picture and picture mengandung langkah-langkah yaitu sajian informasi kompetensi, sajian materi, perlihatkan gambar yang berkaitan dengan materi, siswa mengurutkan gambar sehingga menjadi sistematik, guru mengkonfirmasi gambar tersebut, guru menanamkan konsep sesuai materi bahan ajar, penyimpulan, evaluasi, dan refleksi. Untuk itu, penerapan tipe picture and picture dapat membantu dalam mencapai tujuan pembelajaran. Selain itu, gambar yang menjadi perangkat utama dalam model ini pun tidak terlalu sulit untuk didapatkan.

\section{METODE PENELITIAN}

Penelitian mengenai penerapan cooperative learning tipe picture and picture untuk meningkatkan kemampuan berpikir kronologis siswa dalam pembelajaran sejarah ini menggunakan Penelitian Tindakan Kelas (PTK) sebagai metode penelitiannya. Penelitian ini dapat digolongkan ke dalam tradisi penelitian kualitatif. Ebbut (dalam Wiriaatmadja, 2005, hlm 12) mengemukakan 'penelitian tindakan adalah kajian sistematik dari upaya perbaikan pelaksanaan praktek pendidikan oleh sekelompok guru untuk melakukan tindakan-tindakan dalam pembelajaran, berdasarkan refleksi mereka mengenai hasil dari tindakan-tindakan tersebut.

Berdasarkan permasalahan yang telah ditemukan di lapangan yakni upaya meningkatkan kemampuan berpikir kronologis dalam pembelajaran sejarah di kelas XI IPS 3 SMA Negeri 13 Bandung, maka ini menjadi alasan bagi peneliti untuk menggunakan penelitian tindakan kelas (PTK). Penelitian ini bermaksud untuk meningkatkan proses pembelajaran sejarah khususnya mengenai kemampuan berpikir kronologis yang menjadi fokus dalam penelitian kali ini.

Adapun desain penelitian yang digunakan dalam penelitian ini adalah desain penelitian tindakan model siklus yang diperkenalkan oleh Kemmis dan 
Mc.Taggart, atau lebih dikenal dengan model Kemmis dan Mc. Taggart. Penelitian dilakukan menjadi empat tahapan penting yaitu perencanaan (plan), pelaksanaan (act), pengamatan (observe), dan refleksi (reflect) yang disebut dengan siklus.

Instrumen pengumpulan data dalam penelitian ini terdiri dari lembar observasi, catatan lapangan, dan pedoman wawancara kemudian teknik pengumpulan data yang digunakan dalam penelitian ini berupa observasi, catatan lapangan, wawancara dan studi dokumentasi. Setelah data terkumpul, kegiatan yang dilakukan selanjutnya adalah mengolah data tersebut. Di dalam pelaksanaan penelitian tindakan kelas ini, ada dua jenis data yang dikumpullkan yaitu data kualitatif dan data kuantitatif. Berdasarkan data yang diperoleh pada proses penelitian perlu adanya pengujian atau analisis data. Pada penelitian ini, cara yang dilakukan untuk menguji validasi yaitu dengan melakukan member check, expert opinion dan audit trail.

\section{HASIL PENELITIAN DAN PEMBAHASAN}

Berdasarkan observasi prapenelitian yang telah dilakukan, peneliti mengidentifikasi permasalahan yang ditemukan di kelas dan melakukan perencanaan penerapan model cooperative learning tipe picture and picture untuk meningkatkan kemampuan berpikir kronologis siswa dalam pembelajaran sejarah di kelas XI IPS 3. Adapun perencanaan yang dilakukan oleh peneliti diantaranya mempersiapkan perangkat pembelajaran yang akan digunakan seperti RPP, materi ajar, media pembelajaran, alat evaluasi, instrumen penelitian dan lain sebagainya yang berkaitan dan mendukung pelaksanaan tindakan.

Media yang digunakan oleh peneliti diantaranya gambar-gambar pendukung yang relevan dengan materi ajar, video yang berhubungan dengan materi, dan lembar kerja siswa. Media ini sebagai upaya untuk mempermudah siswa untuk memahami ide, konsep-konsep, dan jalan peristiwa. Sedangkan instrumen yang digunakan antara lain lembar observasi guru dan siswa, serta catatan lapangan untuk mencatat segala aktivitas.

Pelaksanaan tindakan penelitian terdiri daritigabagianyaitukegiatanpendahuluan, kegiatan inti, dan kegiatan penutup. Pada bagian pendahuluan diawali ketika guru menyampaikan salam, mempersilahkan salah seorang siswa untuk memimpin doa sebelum kegiatan pembelajaran dimulai, memeriksa kehadiran siswa, menyampaikan tujuan pembelajaran, dan melakukan kegiatan apersepsi.

Pada kegiatan inti siswa menyimak materi pembelajaran dalam bentuk power point dengan menampilkan gambargambar yang berkaitan dengan materi. Setelah itu siswa diberikan kesempatan untuk bertanya mengenai materi yang telah dijelaskan. Kegiatan selanjutnya adalah siswa membagi diri kedalam kelompok belajar dengan menggunakan model cooperative learning tipe picture and picture. Pada tahap awal, kelompok diberikan pengarahan untuk berdiskusi dan mengidentifikasi gambar-gambar yang sesuai dengan konteks peristiwa. Kemudian siswa diarahkan untuk menyusun kepingan gambar sesuai dengan urutan kronologis. Setelah itu siswa harus mendeskripsikan peristiwa berdasarkan aspek latar belakang, proses berlangsungnya, dan dampak peristiwa dalam lembar kerja siswa. Selain itu siswa 
juga harus memperhatikan aspek struktur temporal, kesinambungan dan perubahan. Kemudian setelah selesai setiap kelompok diharuskan untuk presentasi.

Pada kegiatan penutup, guru bersama dengan siswa melakukan aktivitas penguatan berupa kegiatan mengulang, menuliskan, atau menjelaskan gambar-gambar tersebut. Kemudian siswa dipersilahkan untuk mengumpulkan lembar kerja siswa dan guru menutup kegiatan pembelajaran dengan memberikan motivasi dan mengucapkan salam.
Berdasarkan hasil temuan di lapangan, yaitu selama melakukan penelitian mengenai penerapan model cooperative learning tipe picture and picture untuk meningkatkan kemampuan berpikir kronologis dalam pembelajaran sejarah, memperoleh hasil bahwa kemampuan berpikir kronologis siswa mengalami peningkatan dalam setiap tindakannya. Peningkatan kemampuan berpikir kronologis siswa ketika siswa melakukan aktivitas pembelajaran berlangsung selama empat siklus terlihat dari persentase rata-rata yang dijabarkan dalam tabel berikut ini.

Tabel 1

Perolehan Skor Kemampuan Berpikir Kronologis Siswa

\begin{tabular}{|c|c|c|c|c|c|}
\hline No & \begin{tabular}{|ll} 
Indikator Kemampuan Berpikir \\
Sintesis Siswa
\end{tabular} & Siklus I & Siklus II & Siklus III & Siklus IV \\
\hline 1 & $\begin{array}{l}\text { Kemampuan mengidentifikasi kepin- } \\
\text { gan gambar sesuai dengan konteks } \\
\text { peristiwa yang tepat. }\end{array}$ & 15 & 17 & 23 & 24 \\
\hline 2 & $\begin{array}{l}\text { Kemampuan menyusun kepingan } \\
\text { gambar menjadi urutan kronologis. }\end{array}$ & 12 & 16 & 20 & 24 \\
\hline 3 & $\begin{array}{l}\text { Kemampuan mendeskripsikan peris- } \\
\text { tiwa secara kronologis dalam bentuk } \\
\text { teks berdasarkan gambar (latar be- } \\
\text { lakang peristiwa-jalannya peristiwa- } \\
\text { dampak peristiwa). }\end{array}$ & 11 & 14 & 19 & 20 \\
\hline 4 & $\begin{array}{l}\text { Kemampuan mencantumkan satuan } \\
\text { waktu yang spesifik (tanggal-bulan- } \\
\text { tahun). }\end{array}$ & 13 & 13 & 18 & 23 \\
\hline 5 & $\begin{array}{l}\text { Kemampuanmenunjukkanhubungan } \\
\text { sebab-akibat (kesinambungan dan } \\
\text { perubahan) dalam suatu peristiwa } \\
\text { sejarah. }\end{array}$ & 12 & 12 & & \\
\hline & 18 & 14 & & & \\
\hline 6 & $\begin{array}{l}\text { Kemampuan menceritakan kembali } \\
\text { peristiwa sejarah. }\end{array}$ & 9 & 14 & 21 & 20 \\
\hline & Jumlah Skor Siklus & 72 & 84 & 119 & 125 \\
\hline & Jumlah Skor Maksimal & \multicolumn{4}{|c|}{144} \\
\hline & Rata-Rata (Persentase) & $50,00 \%$ & $58,33 \%$ & $82,63 \%$ & $86,80 \%$ \\
\hline & & & & & \\
\hline
\end{tabular}


Keterangan:

Perhitungan Skor Maksimal = Jumlah Kelompok x Jumlah Indikator (6 indikator x 4 skala penilaian)

$$
\text { Perhitungan Rata-rata (persentase) }=\frac{(\text { Jumlah Skor Siklus })}{(\text { Jumlah Skor Maksimal })} \times 100 \%
$$

Berdasarkan tabel di atas, dapat dilihat bahwa pada siklus ke-I persentase ratarata yang diperoleh adalah 50,00\% dengan kriteria "Cukup". Selanjutnya pada siklus ke-II mulai terlihat adanya peningkatan walaupun tidak terlalu signifikan dengan presentase rata-rata adalah 58,33\% dengan kriteria "Baik". Kemudian pada siklus keIII persentase rata-rata kembali mengalami peningkatan yang cukup signifikan dengan persentase rata-rata sebesar 83,33\% dengan kriteria "Sangat Baik". Pada siklus ke-IV persentase rata-rata kembali mengalami kenaikan sebesar kurang lebih 3\% dimana perolehan persentase ratarata menjadi $86,80 \%$ dengan kriteria nilai "Sangat Baik".

Maka dapat disimpulkan bahwa mulai dari siklus I sampai dengan siklus IV secara keseluruhan, pencapaian indikator kemampuan berpikir kronologis ini mengalami peningkatan yaitu pada indikator ke 1 (kemampuan mengidentifikasi gambar), 2 (kemampuan menyusun kepingan gambar menjadi urutan kronologis), 3 (kemampuan mendeskripsikan peristiwa secara kronologis dalam bentuk teks berdasarkan gambar) dan 4 (kemampuan mencantumkan satuan waktu yang spesifik). Hal tersebut dipengaruhi oleh beberapa faktor diantaranya siswa sudah mulai paham bahwa selalu terdapat gambar jebakan yang diselipkan ke dalam kepingan gambar sehingga pada saat penjelasan dari guru mereka berupaya untuk memperhatikan secara seksama dan menunjukkan keseriusan dalam belajar. Hal tersebut juga diikuti oleh pemahaman yang baik untuk menyusun gambar sehingga menjadi urutan yang kronologis. Kemudian siswa juga sudah mampu menyajikan deskripsi peristiwa yang merepresentasikan setiap kepingan gambar serta berdasar pada aspek latar belakang, jalannya peristiwa, dan sebab akibat. Untuk kemampuan mencantumkan tanggal yang lengkap, dapat dilihat bahwa siswa sudah mulai memahami bahwa perlunya mencantumkan tanggal yang lengkap beserta bulan dan tahun.

$\begin{array}{ccc}\text { Selama } & \text { kegiatan } & \text { penelitian } \\ \text { berlangsung, } & \text { terdapat } & \text { beberapa }\end{array}$ kendala yang dihadapi oleh peneliti dalam menerapkan model cooperative learning tipe picture and picture untuk meningkatkan kemampuan berpikir kronologis siswa dalam pembelajaran sejarah. Adapun kendala-kendala yang dihadapi oleh peneliti selama pelaksanaan tindakan adalah sebagai berikut.

Sulitnya mengkondisikan siswa yang masih kedapatan mengobrol dan bermain gadget pada saat guru menjelaskan materi pembelajaran.

Pada saat aktivitas diskusi kelompok berlangsung, pembagian tugas dalam kelompok masih belum merata dan hanya didominasi oleh satu atau dua orang dalam kelompok tersebut yang dianggap paham dengan materi.

Adanya kesulitan dalam memilih gambaryang representatifdengan peristiwa yang terjadi dan harus menyesuaikan agar 
dapat disusun sesuai dengan peristiwa yang sebenarnya.

Adanya siswa yang mengubah susunan gambar tanpa sepengetahuan guru.

Siswa masih mengabaikan sumber referensi yang seharusnya dicantumkan pada lembar kerja siswa.

Terbatasnya sumber buku pun menjadi kendala sehingga siswa lebih mengutamakan penggunaan gadget untuk mencari dan mengembangkan informasi dari internet.

Berikut ini adalah upaya atau solusi yang dilakukan peneliti untuk menyelesaikan kendala-kendala tersebut.

Guru membiasakan diri untuk mobile ke setiap sudut kelas dan tidak hanya terpaku di depan kelas. Hal ini bertujuan untuk memantau aktivitas siswa yang masih mengobrol dan memainkan gadget, sehingga apabila ditemukan permasalahan tersebut guru dapat langsung bertindak misalnya dengan memberikan pertanyaan ataupun memberikan punishment.

Guru memantau secara bergiliran ke setiap kelompok dan menegaskan kepada siswa untuk bertanggung jawab terhadap masing-masing bagian dan tidak hanya mengandalkan siswa tertentu.

Guru lebih mengeksplorasi sumbersumber gambar baik dari buku, internet, dan lain-lain serta mengidentifikasi gambar terlebihdahulu sehinggaketikapembelajaran berlangsung penggunaan media gambar tidak terlalu menyulitkan siswa.

Guru lebih memaksimalkan penggunaan gambar dan lembar kerja siswa dan menegaskan apabila terdapat salah satu kelompok yang melakukan perubahan susunan maka kelompok tersebut akan dikenakan pengurangan poin.
Guru mengingatkan dan menegaskan siswa pada saat sebelum melakukan diskusi dan pada saat berkeliling kelompok untuk mencantumkan sumber referensi yang didapat.

Guru menugaskan kepada siswa untuk membaca terlebih dahulu mengenai materi yang akan dibahas sebagai bekal pengetahuan awal siswa.

\section{SIMPULAN}

Berdasarkan hasil penelitian tindakan yang telah dilakukan dan pembahasan hasil penelitian yang telah dipaparkan maka dapatdisimpulkanbahwapertama,sebelum diterapkannya model cooperative learning tipe picture and picture peneliti melakukan perencanaan agar penelitian dapat berjalan dengan baik. Hal yang pertama dilakukan adalah dengan melakukan observasi untuk mengidentifikasi permasalahan di kelas XI IPS 3 sehingga peneliti memperoleh gambaran sebelum diterapkannya model cooperative learning tipe picture and picture. Selanjutnya peneliti menghubungi pihak-pihak terkait dalam hal ini adalah sekolah dan guru, menentukan materi berdasarkan hasil diskusi dengan guru mitra, merumuskan rencana pelaksanaan pembelajaran (RPP), menyusun materi ajar, mempersiapkan media seperti gambar yang relevan dengan materi ajar, dan membuat instrumen penelitian. Dengan demikian penelitian yang akan dilakukan dapat berjalan dengan baik sesuai dengan harapan peneliti.

Kedua, pelaksanaan penerapan model cooperative learning tipe picture and picture untuk meningkatkan kemampuan berpikir kronologis ini secara keseluruhan dapat berjalan dengan baik dan dilakukan selama empat siklus. Pelaksanaan diawali 
dengan mengajak siswa untuk menyimak media gambar yang berkaitan dengan materi ajar sebagai kajian utama pembelajaran. Kemudian dilanjutkan dengan aktivitas diskusi yang dibagi menjadi 6 kelompok. Dalam kegiatan tersebut kelompok harus mengidentifikasi gambar yang sesuai dengan konteks peristiwa, mengurutkan gambar menjadi susunan yang kronologis, mencantumkan satuan waktu, menunjukkan hubungan sebab-akibat antara satu gambar dengan gambar lainnya dan dirangkum dalam bentuk tulisan dan selanjutnya kelompok menyajikan hasil diskusi dengan presentasi di kelas.

Ketiga, dengan penerapan model cooperative learning tipe picture and picture, siswa mengalami kemajuan yang cukup signifikan dalam pembelajaran di kelas khususnya dalam kemampuan berpikir kronologis. Melalui penerapan model cooperative learning tipe picture and picture siswa menjadi lebih terbiasa untuk mengurutkan peristiwa dengan dibantu media gambar. Selain itu dengan media gambar siswa juga menjadi lebih paham tentang konteks peristiwa yang sesuai. Siswa juga dilatih untuk dapat menunjukkan hubungan sebab-akibat dan kesinambungan antara gambar satu dengan gambar lainnya dengan bentuk tulisan. Penerapan model cooperative learning tipe picture and picture mampu untuk meningkatkan kemampuan berpikir kronologis dalam pembelajaran sejarah. Hal ini terlihat dari hasil tindakan serta observasi yang dilakukan sebanyak empat kali, di mana dalam setiap tindakan ke-I sampai pada tindakan ke-IV mengalami peningkatan yang cukup signifikan.

Keempat, dalam pelaksanaan penelitian ini peneliti menghadapai berbagai kendala yang harus diatasi oleh peneliti sehingga tidak menghambat pelaksanaan penelitian. Adapun kendalakendala yang dihadapi peneliti diantaranya (1) sulitnya mengkondisikan siswa yang masih kedapatan mengobrol dan bermain gadget pada saat guru menjelaskan materi pembelajaran, (2) pada saat aktivitas diskusi kelompok berlangsung, pembagian tugas dalam kelompok masih belum merata dan hanya didominasi oleh siswa yang dianggap paham dengan materi. (3) kesulitan dalam memilih gambar yang representatif dengan peristiwa yang terjadi danharusmenyesuaikanagardapatdisusun sesuai dengan peristiwa yang sebenarnya, (4) terdapat siswa yang mengubah susunan gambar tanpa sepengetahuan guru, (5) siswa masih mengabaikan sumber referensi yang seharusnya dicantumkan pada lembar kerja siswa, (6) terbatasnya sumber buku sehingga siswa lebih mengutamakan penggunaan gadget untuk mencari dan mengembangkan informasi dari internet.

Berdasarkan pada kendala-kendala tersebut, maka peneliti mengupayakan beberapa solusi untuk setiap permasalahan tersebut yang diantaranya (1) guru membiasakan diri untuk mobile ke setiap sudut kelas dan tidak hanya terpaku di depan kelas, (2) guru menegaskan kepada siswa untuk bertanggung jawab terhadap masing-masing bagian dan tidak hanya mengandalkan siswatertentu,(3)gurulebih mengeksplorasi sumber-sumber gambar baik dari buku, internet, dan lain-lain sehinggatidakterlalumenyulitkansiswa,(4) lebih memaksimalkan penggunaan gambar dan lks dan menegaskan apabila terdapat salah satu kelompok yang melakukan perubahan susunan maka kelompok tersebut akan dikenakan pengurangan poin, (5) mengingatkan dan menegaskan siswa pada saat sebelum melakukan diskusi 
dan pada saat berkeliling kelompok untuk mencantumkan sumber referensi yang didapat, (6) menugaskan kepada siswa untuk membaca terlebih dahulu mengenai materi yang akan dibahas sebagai bekal pengetahuan awal siswa.

\section{DAFTAR PUSTAKA}

Eggen, P \& Kauchak. (2012). Strategi dan Model Pembelajaran: Mengajarkan Konten dan Keterampilan Berpikir. Jakarta: Indeks.

Kemendikbud. (2013) Materi Pelatihan Guru Implementasi Kurikulum 2013: SMA/ MA dan SMK/ MAK Sejarah Indonesia. Jakarta: Badan Pengembangan SDM P dan K Kementerian Pendidikan dan Kebudayaan

Ma'mur, T. (2008). Upaya Meningkatkan Kualitas Pembelajaran Sejarah Melalui Historical Thinking. Bandung: Jurusan Pendidikan Sejarah FPIPS UPI.
Lestari, A.P. (2011). Peningkatan Keterampilan Menulis Cerita Pendek Dengan Model Pembelajaran Picture and Picture (Pada Siswa Kelas II SD Negeri 01 Jaten Karanganyar Tahun Pelajaran 2010/2011). Surakarta: Fakultas Keguruandan Ilmu Pendidikan Universitas Sebelas Maret.

Slavin, R.E. (2008). Cooperative Learning: Teori, Riset, dan Praktik. Bandung: Nusa Media.

Winarto, H. (2014). Penggunaan Media Time Line Untuk Meningkatkan Kemampuan Berpikir Kronologis Siswa (Penelitian Tindakan Kelas di SMA Negeri 15 Bandung) Bandung: Universitas Pendidikan Indonesia.

Wiriaatmadja, R. (2005). Metode Penelitian Tindakan Kelas. Bandung: Remaja Rosda Karya. 